\title{
MAINTENANCE OF A NAVIGABLE CHANNEL THROUGH
}

\author{
A BREAKTHROUGH AREA \\ by $\Lambda . T$. Ippen and D.R.F. Har leman \\ rassahusetts Institute of Technology \\ Cambridgo, Mssachusetts
}

\section{INTRODCTION}

The engineering problem described is one which 18 enoountered on a portion along the Nor theastern cosstine where tidal currents and shifting sands are predominant foatures. Due to the extreme looal variability of such phenomena, generalizations and similar prooodents from whioh a solution might be adopted are seldom available. It is therefore necessary to attempt to reduoe such problems to elements whioh oan be treated by fundamental concepts. With this viewpoint, the proposed solution has been developed by applying elementary principles of energy dissipation to the looal situation of a natural water passago, in which flow due to a tidal differential is essentially in one direction.

\section{BACKGROUND AND GEOGRAPHICAL FEATURES}

The area under oonsideration is located in the town of Chathan at the southesst "elbor" of Cape Cod, Massaohusetts. Fig. I shows the breakthrough which separates the yonomoy Peninsula extending 10 miles south from the mainland. The eastern entrance to the breakthrough is on Pleasant Bay and is proteoted from the Atlantio Ooean by Nauset Beaoh. The westerly ond of the breakthrough leads tnto Stage Harbor and thenoe via the harbor entrance into Nantuoket Sound on the south shore of the Cape.

The present breakthrough dates from the hurricane of 1944, before whioh Monomoy Poninsula was joined to the malnland by a low, narrow beach. The area has a history of earlier breakthroughs and the entire region is noted for marked seasonal ohanges in sand-bar oonfigurations, espeoially at the lower end of Nauset Beach. The eastern entranoe of the break is approximately 1000 feet wide and tapers to 500 feet at 1 ts narrowest seotlon. Observations over several years have shown that the entranoe is beooming wider due to progressive erosion on the Monomoy side, and that the depth in the narrow seotion is inoressing as oonsequence of the inoreasing $f l o w$, whioh due to the existing tidal differential between pleasant Bay and Stage Harbor is essentially in one direction, from east to west.

\section{STA LARNT OF PROBLEM}

The present investigation was initiated because the quantity of sand moving through the break and its subsequent deposition is reapidly threatening the usefulness of the Stage Harbor anchorage and maneuvering area. There is a definite insentive for early action with a deoision to be made whother to close the break ontirely or to maintein narigation through the out due to its demonstrated usefulness as a 20-mile nautioal short-out from Stage Barbor to the boating and fishing areas of the east shore of the Cape. The speoific requirements of the solution may be summarised as follows:

\footnotetext{
Presented at the Third Conference on Coastal Engineering.
} 


\section{MAINTENANCE OF A NAVIGABLE CHANNEL THROUGH}

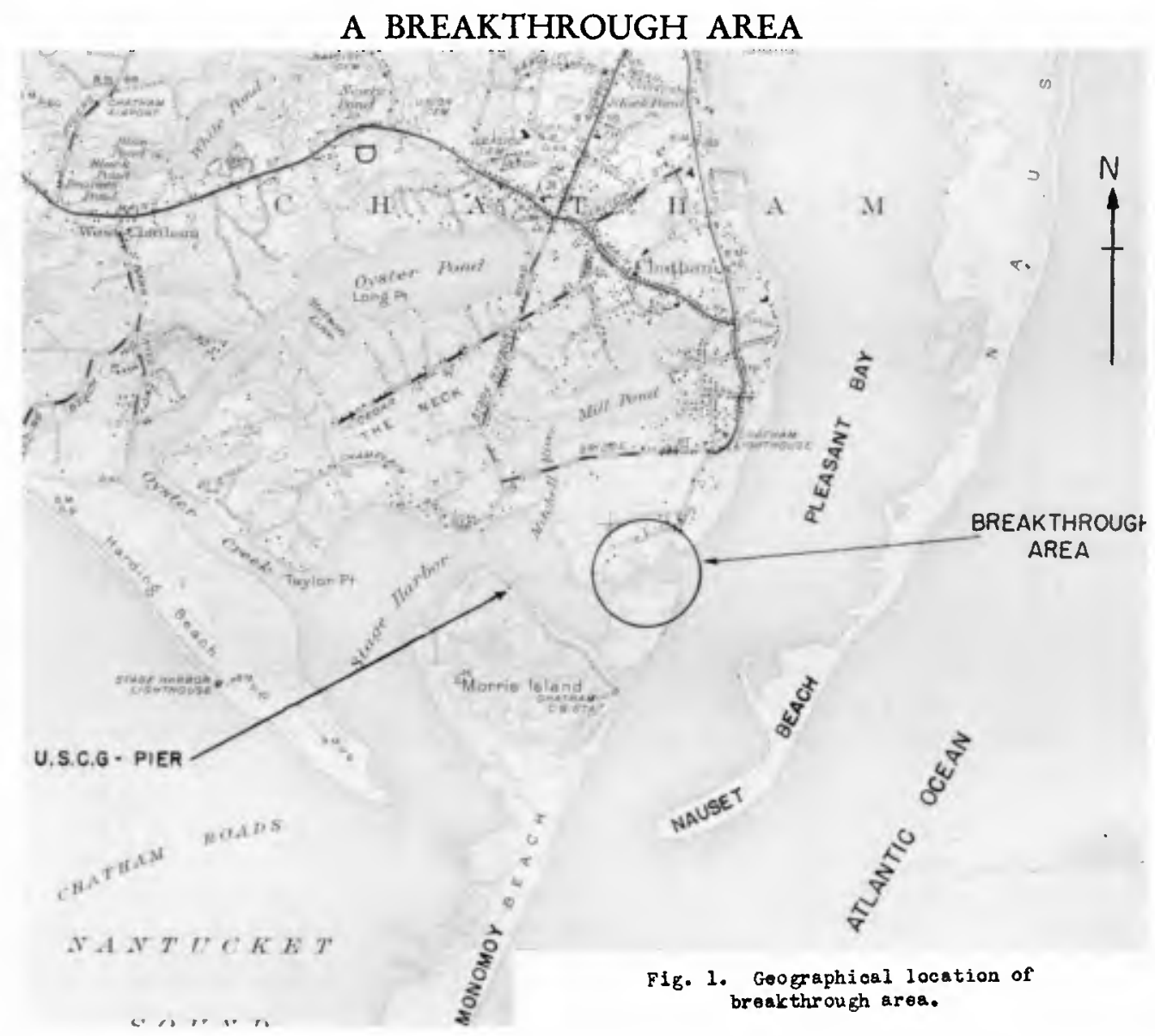

Figure 1.

(a) The sand movement through the break is to be reduced to an amount oonsistont with maintaining Stago Harbor.

(b) A navigablo waterway is to be provided if oompatiblo with (a).

(o) Any proposed struotures should in no way ondanger present lowlovel bulldings in the adjacont areas.

\section{SUDMAR OF OBSERVA TIOIS}

Simultaneous water-lovel observations during one tidal oyole establishod the faot that undor moan tidal considerations, a water oloration difforontial of approximately four lnohes exista at high tide between the extreme onds of the breakthrough. The mean tide range for this area is 3.6 foot. Sinoe the highor elevation oocurs on the eastorn or Atlantio side, a strong wosterly curront transporting large quantitios of sand 18 produoed. Fig. 2 is an aerial photograph looking wost from the broakthrough ontrance toward Stage Harbor showing the direotion of the tidal ourrent as dotermined from the oriontation of sand ripples along the bottom. Velocitios in excose of throe knots have been observed in the narrow portion under mean tidal oonditions. Fig. 3 is a similar photograph looking from Stago Harbor in an oasterly diroction toward the broakthrough shoring the position of the 


\section{COASTAL ENGINEERING}

shelf of doposited sand as of February 1952. A comparison of previous surveys indicates a yoarly doposition of 50,000 cublo yards of sand and a movement of the shelf into Stage Harbor at the rate of 100 feet per year. At low tide, the shelf is dry except for a narrow channel containing less then one foot of water, and under present conditions the breakthrough is narlgable to small boats from about two hours before to two hours following high tide, at which time there is approximately 4 - 5 foet of water in the channel. The Cosst Guard launching pier in the right conter of Figb 3 has been abandoned due to the prosence of the sand shelf. Largo steop-fronted sand ripples mossuring 7 - 10 foot in longth and $3-6$ inches in height have been observed in this area during low tide.

\section{FROPOSED SOLUTIOI}

It is evident that the amount of sand transport into the harbor is related to the rolume rate of flow through the break and that its reduotion is dopendent on dooreasing this flow rate during the high-tide periods. Any solution of course must consider the eoononite aspects of the problem. It 18 therefore proposed that the discharge be reduced by minimizing both the oross-sectional area and the velocities of flow in the following manner,

Reduction of cross section can be aohieved by construotion of dikes from either shore leaving an opentng to be determined by navigation roquirements. Reduotion of velocities on the other hand cannot be brought about by aimple reduction of area, inasmuoh as the tidal hoad difforontial is ossentially indopendent of the total rate of flow through the break. Velooities, therefore, can be reduoed only by inoreasing ener dissipation suoh as might be obtained by greator ohannel roughness or by making use of turbulent dissipation at flow expansions. The lattor mothod can be offeotively achieved by oonstruoting several dikes with narigation openings in series with subsequent energy dissipation across each flow constriotion. The number of dikes is necessarily limited by coonomical oonsiderations and the present proposal incorporates two such struotures. Fach dike would have a 30-foot navigation oponing proteoted by wingralls and a bottom sill of propor helght to prevent under-cutting and scour at the construoted sootion, as woll as to prevent sand movement without obstruoting passage of small boats. Assuming that one-half of the total four-inoh head differenoe ocours across each oonstriotion, a volocity of approximately two knots may be expeoted looally in these openings as compared with velocitios in excess of three knots under present oonditions or with a single dike. It is estimated that 33 percent reduotion in velocity coupled with the deorease in oross section would result in a flow of the order of 10 peroent of the present rate under similar tidal conditions. It is probablo that the rate of sand transport would be reduced to a greater extent than is indioated by the deorease in the flow rate. In addition, the doep pool between the two dikes would act as a sand trap for 8 cono of the material ontering through the outer dike. Fig. \& is a sohematio view of the general area showing the looktion of the proposed dikes in relation to the breakthrough. A navigable waterway which will perait passage of small oraft throughout the tidal oyole could be obtained by dredging a channel on the existing sand sholf as indioated.

Hg. 5 shows a oross seotion along the navigation ohannel extending from Stago Harbor through the break into Pleasant Bay. The function of the sills in roduoing sand movement and tho deop portion botwoen the dikes are olearly 1llustrated. 
MAINTENANCE OF A NAVIGABLE CHANNEL THROUGH

A BREAKTHROUGH AREA

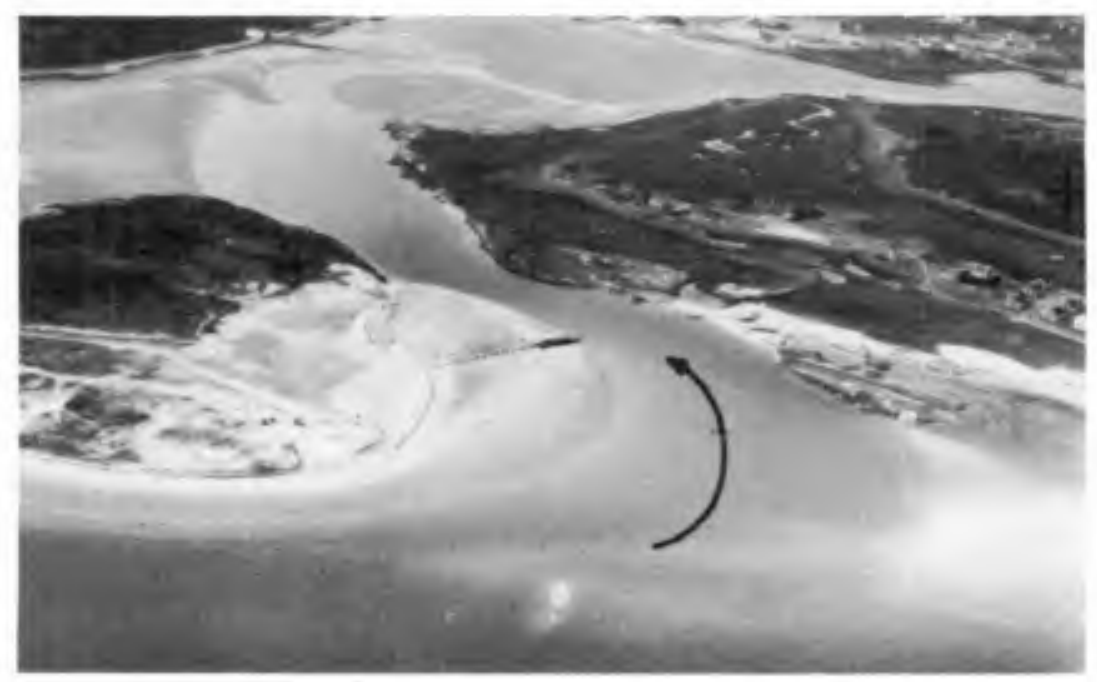

Fig. 2. Entrance to breakthrough looking

toward Stage Harbor at low tide.

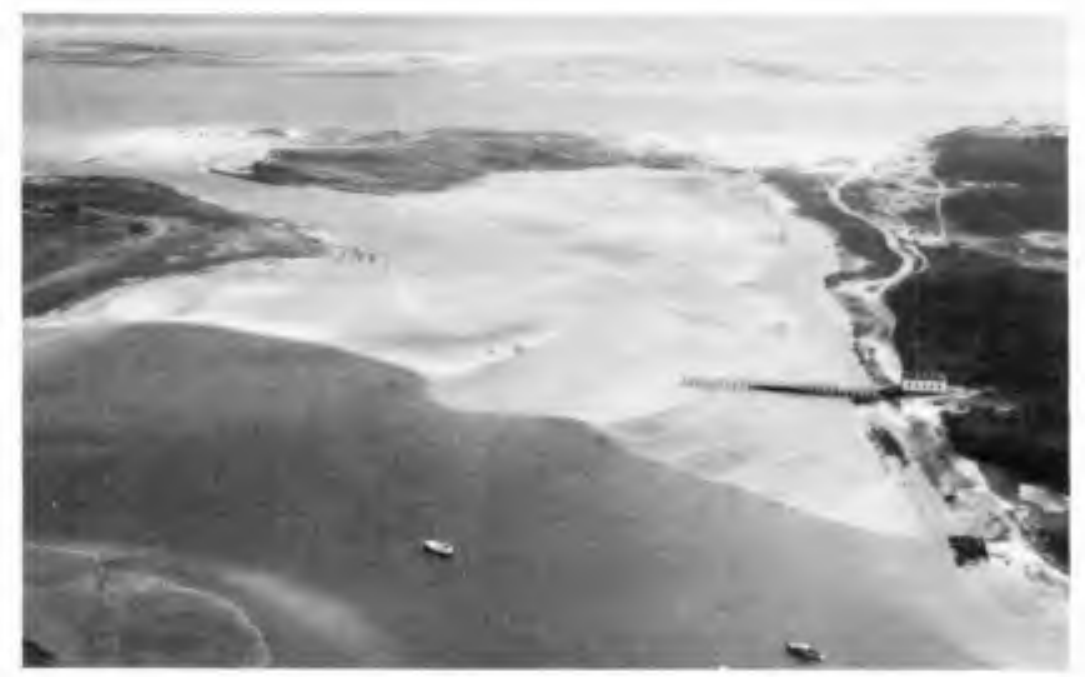

Fig. 3. Position of sand shelf at Stage Harbor at end of broakthrough (Feb. 1952). 


\section{COASTAL ENGINEERING}

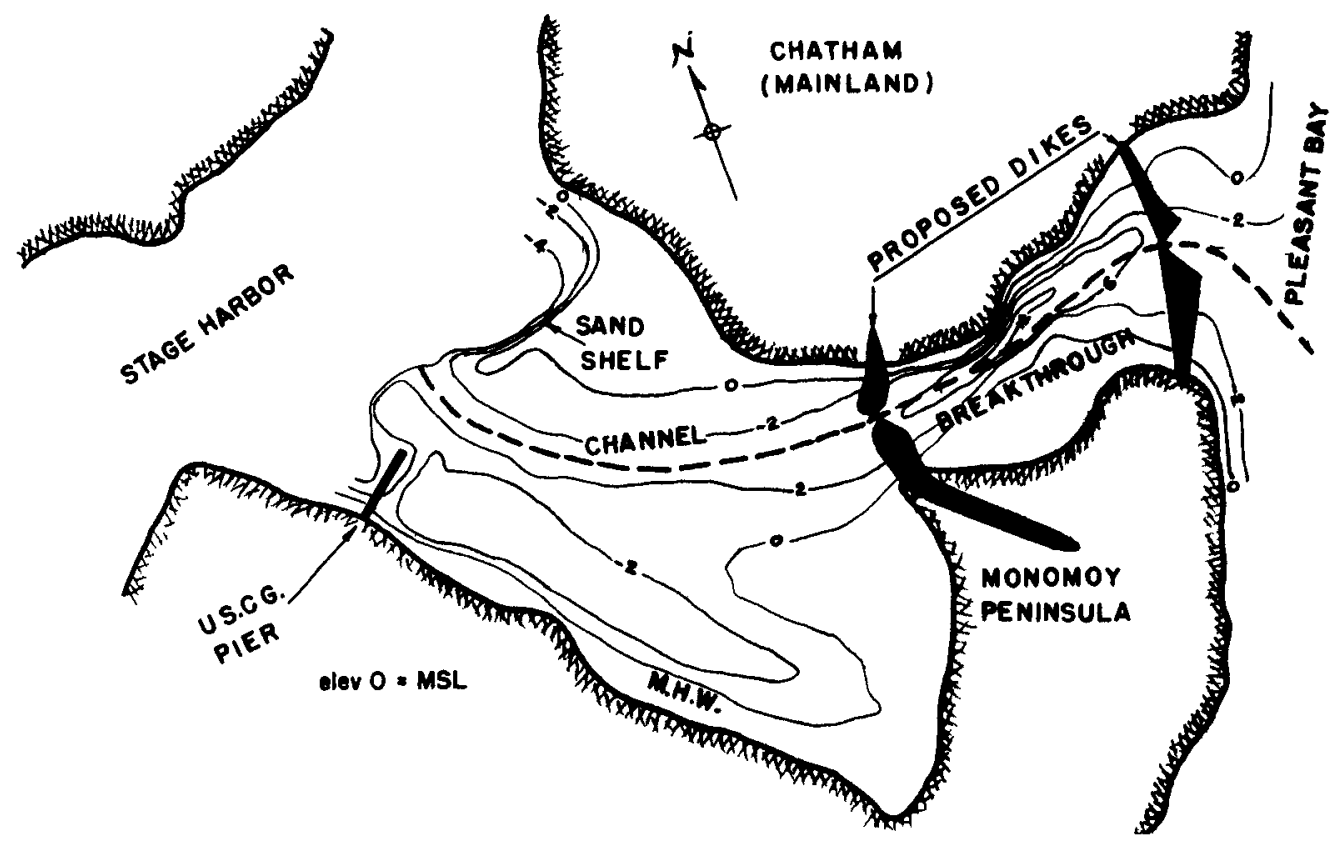

Fig. 4. Sohematio view of breakthrough showing location of proposed dikes.

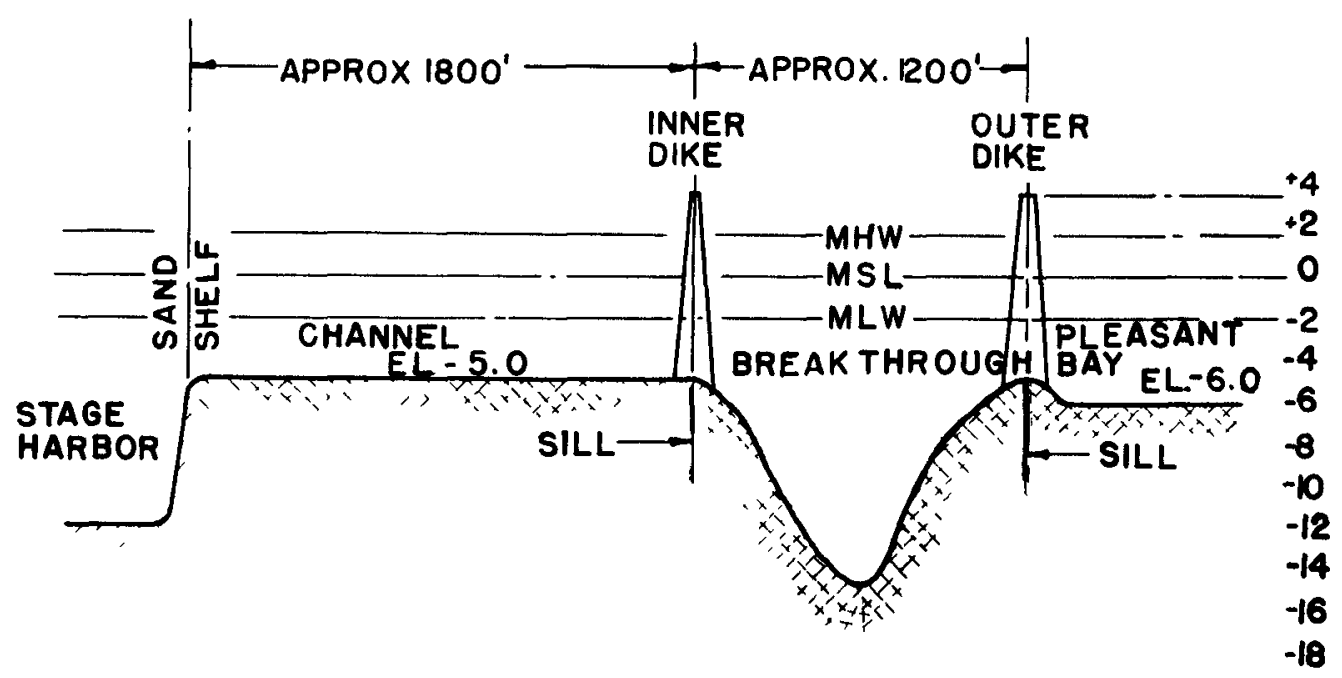

Fig. 5. Cross seotion along ohannel between outer dike and Itage Harbor. 


\section{MAINTENANCE OF A NAVIGABLE CHANNEL THROUGH}

\section{A BREAKTHROUGH AREA}

The elevation of the top of the dikes would be two feet above mean high water, due to the presenoe of existing buildings at elevation 3.5 feet above M.H.W. It is therefore necessary that storm tides orer top the dikes so as not to endanger this property. Under these conditions, the outer dike would act as a wolr having a orest length of over 1000 feet. The dikes are well protected against wave action from the open ocoan by Nauset Beach. Observations during a severe storm showed waves breaking across this offshore bench and very little wave action in the vicinity of the breakthrough.

In a small engineering profect such as this, estimated costs had to be held to an absolute minimum so therefore the dikes are proposed to be construeted as treated timber bulkheads of the type commonly used in beach groin construotion. Sand obtained from dredging would be used as fill on either side of the sheot piling. 